Research Article

\title{
THE EFFECT OF VOCABULARY MASTERY AND READING INTEREST TOWARDS THE ABILITY TO COMPREHEND RECOUNT TEXT
}

\author{
Evi Agustin ${ }^{1}$, \\ Syahfitri Purnama ${ }^{2}$, \\ Postgraduate Program, Universitas Indraprasta PGRI \\ e-mail: evi.agustin.rib22@gmail.com ${ }^{1}$ \\ e-mail: syahfitripurnama@gmail.com ${ }^{2}$
}

\begin{abstract}
Abstrak: Penelitian ini bertujuan untuk mengetahui pengaruh penguasaan kosakata dan minat baca terhadap kemampuan memahami teks recount. Hipotesis penelitian yang diuji meliputi: 1) Pengaruh Penguasaan Kosakata terhadap Kemampuan Memahami Teks Recount, 2) Pengaruh Minat Baca terhadap Kemampuan Memahami Teks Recount, 3) Pengaruh Penguasaan Kosakata dan Minat Baca secara bersama-sama terhadap Kemampuan Memahami Teks Recount. Penelitian dilakukan dengan menggunakan metode survei dengan jumlah sampel 66 (enampuluh enam) siswa SMP Negeri di Kabupaten Indramayu.. Instrument yang digunakan adalah angket dan hasil tes bahasa Inggris bentuk pilihan ganda dengan pilihan 20 soal penguasaan kosakata dan 20 soal mengenai teks recount. Data diolah dengan menggunakan bantuan SPSS 20 dan dianalisis dengan menggunakan analisis regresi. Berdasarkan hasil pengujian hipotesis, diperoleh kesimpulan: 1) Pengaruh Penguasaan Kosakata berpengaruh langsung terhadap Kemampuan Memahami Teks Recount, 2) Penguasaan Minat Baca berpengaruh langsung terhadap Kemampuan Memahami Teks Recount, 3) Pengaruh Penguasaan Kosakata dan Minat Baca secara bersama-sama berpangaruh langsung terhadap Kemampuan Memahami Teks recount.
\end{abstract}

Kata kunci: Penguasaan kosakata, minat baca, teks recount.

\section{Pendahuluan}

Bahasa merupakan alat komunikasi yang penting bagi manusia. Tanpa bahasa, manusia tidak dapat menyampaikan keinginan atau maksudnya secara jelas. Bahasa senantiasa mendampingi kegiatan manusia untuk berkomunikasi sehari-hari. Bahasa juga dikenalkan pada manusia sejak kecil oleh orang tuanya. Selain orang tua, lingkungan mempengaruhi pembentukan bahasa seseorang. Pembentukan bahasa juga dikenalkan dalam pendidikan formal, yaitu sekolah. Memperkenalkan keterampilan berbahasa di sekolah merupakan dasar untuk mengembangkan ide, pikiran, gagasan, dan perasaan ke dalam bahasa lisan maupun tulis.

Keterampilan berbahasa terdiri atas empat komponen, yaitu keterampilan menyimak, berbicara, membaca, dan menulis. Keempat komponen tersebut menjadi satu kesatuan yang utuh pada saat pengenalan terhadap bahasa. Hal yang pertama dilakukan adalah proses mendengarkan, kemudian muncul proses meniru hasil mendengarkan dengan berbicara. Tahap selanjutnya, seseorang akan berlatih membaca untuk mengenal berbagai macam tulisan dari proses mengenal huruf hingga proses merangkai huruf menjadi kata, frasa, atau kalimat.

Membaca merupakan kegiatan yang sangat penting dan bermanfaat bagi kehidupan seseorang. Membaca membuat seseorang banyak memperoleh pengetahuan dan wawasan yang luas. Meskipun saat ini pemakaian alat-alat elektronik sudah semakin maju dan meluas. Kemampuan membaca yang dimaksud adalah kemampuan dalam memahami isi suatu bacaan. Pemahaman membaca merupakan kemampuan yang sangat penting, seorang siswa akan lebih mudah dalam memperoleh informasi dari berbagai macam bacaan. Bagi siswa, pemahaman terhadap suatu bacaan merupakan sukses dalam meraih keberhasilan di sekolah. Kemampuan membaca seseorang dipengaruhi oleh berbagai faktor. Faktor- faktor pokok tersebut, yaitu faktor linguistik (kebahasaan) dan faktor non-linguistik. Faktor kebahasaan yang dimaksud, yakni keterampilan berbahasa dalam arti kompetensi berbahasa dan intelegensi seseorang yang meliputi 
penguasaan tata bahasa, morfologi, sintaksis, dan kosakata, sedangkan faktor non-linguistik berupa latar belakang pengalaman yang berhubungan dengan berbagai afeksi atau kondisi psikologi peserta didik, seperti motivasi, minat sikap, dan kepercayaan atau pandangan.

Kebutuhan dalam pendidikan semakin meningkat, dan tuntutan meningkatnya hasil belajar juga merupakan hal yang mendasar dalam memenuhi tuntutan globalisasi dan ilmu pengetahuan. Faktor yang diduga ikut mempengaruhi hasil belajar adalah minat dan motivasi belajar. Kompetensi profesional guru yang kurang dilandasi minat dan motivasi belajar yang rendah akan menimbulkan rendahnya hasil pembelajaran atau keterampilan yang dimiliki peserta didik. Sebaliknya kompetensi profesional yang didorong oleh minat dan motivasi belajar yang tinggi akan menunjang terciptanya proses pembelajaran yang efektif dan efisien.

Minat adalah kecenderungan yang tetap untuk memperhatikan dan mengenang beberapa kegiatan. Kegiatan yang diminati seseorang, diperhatikan terus-menerus yang disertai dengan rasa senang. Jadi berbeda dengan perhatian karena perhatian sifatnya sementara (tidak dalam waktu yang lama) dan belum tentu diikuti dengan perasaan sehingga diperoleh kesenangan. Demikian pula dengan seseorang yang berminat dengan kegiatan membaca, maka ia akan cenderung perhatian, senang, dan akrab dengan bacaan. Minat baca merupakan keinginan atau ketertarikan seseorang terhadap suatu bacaan yang kemudian mendorongnya untuk memahami atau bahkan menelaah lebih lanjut bacaan yang diinginkannya. Tinggi rendahnya minat membaca ini dapat dilihat dari intensitas dalam mengakrabkan bahan bacaan.

Peneliti memilih teks recount sebagai acuan penelitian karena teks recount merupakan pembelajaran teks bagi siswa kelas VIII serta teks recount merupakan teks yang beris kejadian yang telah lalu. Tujuan komunikatif teks recount adalah untuk menceritakan kejadian yang telah lalu

Pelaksanaan pembelajaran keterampilan berbahasa, khususnya keterampilan membaca di sekolahsekolah, kebanyakan dari mereka hanya mengandalkan aspek teoretis yang berupa sumber dari buku cetak tanpa memerhatikan metode atau media yang mendukung dalam pembelajaran. Perkembangan minat baca dan kemampuan membaca masyarakat khusus siswa sekolah sangat memprihatinkan. Hal ini disebabkan metode yang diberikan kepada siswa umumnya kurang menarik dan tidak menyenangkan. Sebagian besar metode yang ada hanya berorientasi pada hasil bukan pada proses. Selain itu, perkembangan teknologi internet belum dimanfaatkan dengan baik. Seharusnya perkembangan teknologi internet membawa dampak terhadap peningkatan minat baca, karena internet merupakan sarana visual yang dapat dijadikan sumber informasi, tetapi hal ini disikapi lain, karena pada kenyataannya yang dicari di internet sebagian besar berupa visual yang kurang tepat bagi konsumsi siswa, sehingga justru mengalihkan perhatian anak-anak (siswa) pada buku. Rendahnya minat baca siswa menjadikan kebiasaan membaca yang rendah, dan berpengaruh pada kemampuan membaca.

Berdasarkan uraian yang sudah dijelaskan di atas bahwa penulis mencoba meneliti pengaruh penguasaan kosakata dan minat baca terhadap kemampuan memahami teks recount di SMP Negeri Kabupaten Indramayu. Berdasarkan latar belakang masalah tersebut di atas, maka penulis dapat merumuskan masalah sebagai berikut.

1. Apakah terdapat pengaruh penguasaan kosakata dan minat baca secara bersama-sama terhadap kemampuan memahami teks recount, siswa SMP Negeri di Kabupaten Indramayu?

2. Apakah terdapat pengaruh penguasaan kosakata terhadap kemampuan memahami teks recount, siswa SMP Negeri di Kabupaten Indramayu?

3. Apakah terdapat pengaruh minat baca terhadap kemampuan memahami teks recount, siswa SMP Negeri di Kabupaten Indramayu?

Berdasarkan rumusan masalah tersebut, penelitian ini memiliki tujuan untuk mengetahui:

1. Pengaruh penguasaan kosakata dan minat baca secara bersama-sama terhadap kemampuan memahami teks recount.

2. Pengaruh penguasaan kosakata terhadap kemampuan memahami teks recount.

3. Pengaruh minat baca terhadap kemampuan memahami teks recount.

\section{Metode}

Penelitian akan dilaksanakan di SMP Negeri di Kabupaten Indramayu tahun pelajaran 2019/2020. Objek dalam penelitian ini adalah para siswa kelas VIII SMP Negeri di Kabupaten Indramayu, adapun jumlah SMP Negeri di Kabupaten Indramayu Provinsi Jawa Barat. Penelitian ini direncanakan yaitu bulan 


\section{INFERENCE: Journal of English Language Teaching}

Vol. 3, No. 3, December 2020 - March 2021

p-ISSN: 2615-8671

e-ISSN: 2615-868X

November 2019. Metode penelitian yang digunakan penulis selama penelitian adalah metode survei yaitu dengan mendatangi langsung objek penelitian sedangkan pendekatan analisis yang digunakan adalah korelasional. Artinya penelitian untuk mengetahui pengaruh dua variabel terikat dengan satu variabel bebas. Dalam penelitian ini populasi adalah seluruh siswa kelas VIII SMP Negeri di Kabupaten Indramayu Provinsi Jawa Barat.

Pengambilan sampel menurut Ridwan (2009:70) apabila subjek kurang dari 100, maka lebih baik diambil semua, sehingga penelitiannya merupakan penelitian populasi. Selanjutnya jika subjeknya besar dapat diambil antara 10\% - $15 \%-25 \%$ atau lebih. Dalam penelitian ini, peneliti menggunakan teori Ridwan untuk pengambilan sampel sehingga diperoleh jumlah sampel seperti dalam tabel berikut:

Tabel. 1

Penetapan Jumlah Anggota Sampel

\begin{tabular}{|l|l|c|c|}
\hline No & \multicolumn{1}{|c|}{ Nama Sekolah } & Populasi Kelas & $\begin{array}{c}\text { Jumlah Sampel } \\
\mathbf{( 1 0 \% )}\end{array}$ \\
\hline 1 & SMP Negeri 1 Sindang & 326 & 33 \\
\hline 2 & SMP Negeri Unggulan & 330 & 33 \\
\hline \multicolumn{2}{|c|}{ Jumlah } & $\mathbf{6 5 6}$ & $\mathbf{6 6}$ \\
\hline
\end{tabular}

Metode pengumpulan data dalam penelitian ini menggunakan metode kuesioner dan tes. Kuesioner digunakan untuk mendapatkan data tentang minat baca, sedangkan tes digunakan untuk mengukur penguasaan kosakata dan kemampuan memahami teks recount. Instrumen yang digunakan untuk memperoleh data dalam penelitian ini adalah tes dan non tes. Tes dilakukan untuk penguasaan kosakata dan kemampuan memahami teks recount dengan memberikan soal pilihan ganda, sedangkan untuk instrumen non tes dengan memberikan kuesioner tentang data minat baca.

\section{Hasil dan Diskusi}

\section{Deskripsi Data}

Dalam bab ini penulis menyajikan data penelitian untuk variabel penguasaan kosakata $\left(\mathrm{X}_{1}\right)$, minat baca $\left(\mathrm{X}_{2}\right)$, dan kemampuan memahami teks recount $(\mathrm{Y})$ ditampilkan deskripsi statistik dari hasil perhitungan dan pengujian yang dilakukan dengan bantuan komputer melalui program aplikasi SPSS 20, serta analisis dan interpretasinya.

Tabel 2.

Deskripsi Data Penelitian Statistics

\begin{tabular}{|l|r|r|r|}
\hline & $\begin{array}{c}\text { Penguasaan } \\
\text { Kosakata }\end{array}$ & Minat Baca & $\begin{array}{c}\text { Kemampuan } \\
\text { Memahami } \\
\text { Teks Recount }\end{array}$ \\
\hline $\mathrm{N} \quad$ Valid $\quad$ Missing & 66 & 66 & 66 \\
Mean & 0 & 0 & 0 \\
Median & 65.15 & 80.94 & 63.00 \\
Mode & 60.00 & 80.50 & 60.00 \\
Std. Deviation & 60 & 77 & 60 \\
Skewness & 12.464 & 11.090 & 14.213 \\
Std. Error of Skewness & .352 & .028 & .314 \\
Kurtosis & .295 & .295 & .295 \\
Std. Error of Kurtosis & -601 & -.386 & -.823 \\
Range & .582 & .582 & .582 \\
Minimum & 50 & 50 & 50 \\
Maximum & 40 & 52 & 40 \\
& 90 & 102 & 90 \\
\hline
\end{tabular}

\section{Analisa Data Kemampuan Memahami Teks Recount (Y)}

Data kemampuan memahami teks recount diperoleh dari para 66 responden berdasarkan tabel 4.1 atas di dapatkan bahwa mempunyai rata-rata 63.00 dengan simpangan baku 14.213, median sebesar 60.00, 
INFERENCE: Journal of English Language Teaching

Vol. 3, No. 3, December 2020 - March 2021

p-ISSN: 2615-8671

e-ISSN: 2615-868X

Modus 60, skor minimum 40 dan skor maksimum 90 . Hal ini menunjukkan bahwa rata-rata kemampuan siswa untuk memahami teks recount dari 66 responden siswa SMPN Unggulan Sindang dan SMPN 1 Sindang relatif cukup baik,

Dari deskripsi tersebut juga dapat dilihat bahwa antara nilai rata-rata dan dan nilai tengah (median) hampir sama, yaitu 63.00 dan 60.00. Hal ini menunjukkan bahwa data skor Kemampuan memahami teks recount pada penelitian ini cukup representatif.

2. Analisis Data Variabel Penguasaan Kosakata $\left(\mathbf{X}_{1}\right)$

Skor Penguasaan Kosakata yang diperoleh dari para responden siswa SMPN Unggulan Sindang dan SMPN 1 Sindang mempunyai rata-rata 65.15 dengan simpangan baku 12.464, median sebesar 60, modus sebesar 60, skor minimum 40 dan skor maksimum 90. Berdasarkan tabel 4.1 diatasi dapat dikatakan bahwa penguasaan kosakata pada siswa SMPN Unggulan Sindang dan SMPN 1 Sindang cukup baik. Hal ini diindikasikan dengan perolehan nilai rerata skor kosakata 65.15 .

3. Analisis Data Minat Baca $\left(\mathbf{X}_{2}\right)$

Data Minat baca diperoleh dari kuesioner yang dijawab oleh 66 responden mempunyai rata-rata 80.94 dengan simpangan baku 11.090 median 80.50 skor minimum 52 dan skor maksimum 102. Berdasarkan data pada tabel 1 di atas bisa dikatakan bahwa minat baca siswa SMPN Unggulan Sindang dan SMPN 1 Sindang cukup baik. Hal ini diindikasikan dengan perolehan skor rerata sebesar 80.94 lebih tinggi dari nilai mediannya yaitu 80.50 .

\section{Pengujian Hipotesis dan Pembahasan}

Pengajuan hipotesis dilakukan sesuai dengan ketentuan yang telah dijelaskan dalam Bab III. Hasil perhitungan dan pengujian bisa dilihat pada Tabel 3 di bawah ini

Tabel 3

Hasil Perhitungan Pengujian Koefisien Korelasi Ganda Variabel $X_{1}$ dan $X_{2}$ terhadap Y Model Summary

\begin{tabular}{|l|r|r|r|r|}
\hline Model & R & R Square & \multicolumn{1}{c|}{$\begin{array}{c}\text { Adjusted R } \\
\text { Square }\end{array}$} & $\begin{array}{c}\text { Std. Error of the } \\
\text { Estimate }\end{array}$ \\
\hline 1 & $.951^{\mathrm{a}}$ & .905 & .902 & 4.449 \\
\hline
\end{tabular}

a. Predictors: (Constant), Minat Baca, Penguasaan Kosakata

Tabel 4

Hasil Perhitungan Pengujian Signifikansi Koefisien Regresi Variabel $\mathrm{X}_{1}$ dan $\mathrm{X}_{2}$ terhadap $\mathrm{Y}$ ANOVA $^{\mathrm{a}}$

\begin{tabular}{|c|c|c|c|c|c|}
\hline Model & Sum of Squares & df & Mean Square & $F$ & Sig. \\
\hline Regression & 11883.187 & 2 & 5941.593 & 300.222 & $.000^{\mathrm{b}}$ \\
\hline Residual & 1246.813 & 63 & 19.791 & & \\
\hline Total & 13130.000 & 65 & & & \\
\hline
\end{tabular}

a. Dependent Variable: Kemampuan Memahami Teks Recount

b. Predictors: (Constant), Minat Baca, Penguasaan Kosakata 
Tabel 5

Hasil Perhitungan Persamaan Regresi Ganda Variabel $\mathrm{X}_{1}$ dan $\mathrm{X}_{2}$ terhadap Y

Coefficients $^{\mathrm{a}}$

\begin{tabular}{|ll|l|l|l|l|l|}
\hline Model & & \multicolumn{2}{|l|}{$\begin{array}{l}\text { Unstandardized } \\
\text { Coefficients }\end{array}$} & $\begin{array}{l}\text { Standardized } \\
\text { Coefficients }\end{array}$ & & \multirow{2}{*}{ Sig. } \\
\cline { 2 - 4 } & \multicolumn{1}{|c|}{$\mathrm{B}$} & td. Error & Beta & & \\
\hline \multirow{2}{*}{1} & (Constant) & 22.070 & .290 & & -5.145 & 000 \\
& Penguasaan Kosakata & 646 & 093 & .566 & 6.959 & 000 \\
& Minat Baca & 531 & 104 & .415 & 5.096 & 000 \\
\hline
\end{tabular}

a. Dependent Variable: Kemampuan Memahami Teks Recount

\section{Pengaruh Penguasaan Kosakata $\left(X_{1}\right)$ dan Minat Baca $\left(X_{2}\right)$ secara bersama-sama terhadap Kemampuan Memahami Teks Recount $(Y)$}

Hipotesis pengaruh ini adalah :

$$
\begin{aligned}
& \mathrm{H}_{0}: \beta_{1}=\beta_{2}=0 \\
& \mathrm{H}_{1}: \beta_{1} \neq 0 \text { dan } \beta_{2} \neq 0
\end{aligned}
$$

Tabel 4 dapat dinyatakan bahwa terdapat pengaruh yang signifikan penguasaan kosakata dan minat baca secara bersama-sama terhadap kemampuan memahami teks recount. Hal ini dibuktikan dengan perolehan nilai Sig $0.00<0,05$ dan $F_{h}=300.222$. Dalam kegiatan membaca terdapat banyak faktor yang mempengaruhi kemampuan membaca terutama dalam kegiatan membaca bacaan berbahasa Inggris. Somadayo (2011: 31-32) menyebutkan bahwa faktor yang dapat mempengaruhi kemampuan membaca seseorang ada faktor kemampuan berbahasa atau kosakata dan minat. Apabila seseorang dalam melakukan kegiatan membaca terdapat dorongan dari dalam dirinya untuk membaca maka akan lebih mudah dan bersemangat dalam memahami bacaan yang dihadapi. Begitu pula apabila seseorang menghadapi bacaan yang bahasanya tidak pernah didengarnya maka akan sulit memahami teks bacaan tersebut, penyebabnya tidak lain adalah kosakata yang dimiliki seseorang tersebut. Dengan demikian dua faktor tersebut yaitu minat baca dan penguasaan kosakata pada seseorang maka akan mempengaruhi kemampuan membaca pemahamannya yang dimilikinya. Teks recount merupakan teks yang harus dipahami oleh siswa SMP, hal ini sesuai dengan kompetensi inti dan kompetensi dasar yang terdapat pada kurikulum 2013. Teks recount dianggap sulit karena siswa tidak memahami maksud atau arti kosakata bahasa Inggris yang digunakan pada teks recount. Selain itu, siswa akan sulit memahami teks recount jika mereka jarang membaca teks berbahasa Inggris. Oleh karena itu, siswa harus memiliki minat membaca teks berbahasa Inggris dan menguasai kosakata bahasa Inggris untuk memahami teks recount. Dari informasi kuantitatif dan teori tersebut maka peneliti berasumsi bahwa terdapat pengaruh yang signifikan penguasaan kosakata dan minat baca secara bersama-sama terhadap kemampuan memahami teks recount siswa SMP Negeri di Kabupaten Indramayu

Pengaruh Penguasaan Kosakata $\left(X_{I}\right)$ terhadap Kemampuan Memahami Teks Recount (Y) Hipotesis pengaruh ini adalah :

$$
\begin{array}{ll}
\mathrm{H}_{0}: & \beta_{1}=0 \\
\mathrm{H}_{1}: & \beta_{2} \neq 0
\end{array}
$$

Tabel 5. dapat dinyatakan bahwa terdapat pengaruh yang signifikan penguasaan kosakata terhadap kemampuan memahami teks recount. Hal ini dibuktikan dengan perolehan nilai Sig. $0.000<0,05$ dan $\mathrm{t}_{\mathrm{h}}=$ 6.959. Penguasaan terhadap aspek kosakata pada dasarnya memberi pengaruh terhadap kualitas penggunaan bahasa seseorang. Artinya, penggunaan bahasa yang baik menjadi cermin penguasaan kosakata yang memadai. Namun sebaliknya, penguasaan bahasa yang kurang baik biasanya terjadi akibat penguasaan kosakata yang kurang baik. Sebagai konsekuensi dari penggunaan bahasa dan penguasaan kosakata yang kurang baik maka proses dan makna komunikasi yang dilakukan menjadi optimal. Penguasaan kosakata adalah aspek penting dalam kemampuan berbahasa terutama dalam kemampuan berbahasa Inggris seperti pendapat Tarigan (2015:2) menjelaskan bahwa kualitas keterampilan berbahasa seseorang bergantung pada kuantitas dan kualitas kosakata yang dimilikinya. Semakin kaya kosakata yang dimiliki, semakin besar pula kemungkinan kita terampil berbahasa. Hal ini berarti bahwa penguasaan 
kosakata seseorang menentukan kualitas berbahasa orang tersebut. Tanpa mempunyai penguasaan kosakata yang memadai maka sangat sulit bagi orang tersebut untuk mengadakan interaksi secara baik. Jika siswa tidak memiliki penguasaan kosakata maka siswa tidak dapat mencapai kemampuan berbahasa Inggris. Salah satu kemampuan berbahasa Inggris adalah membaca memahami isi sebuah teks. Untuk dapat memahami sebuah teks berbahasa Inggris maka siswa harus memiliki penguasaan kosakata yang baik. Salah satu teks dalam materi pelajaran bahasa Inggris di SMP adalah teks recount. Teks recount adalah teks yang menceritakan sebuah peristiwa yang terjadi di masa lampau. Oleh karena itu, siswa harus memiliki penguasaan kosakata untuk memahaminya.

\section{Pengaruh Minat Baca $\left(\mathbf{X}_{2}\right)$ terhadap Kemampuan Memahami Teks Recount (Y)}

Hipotesis pengaruh ini adalah :

$$
\begin{aligned}
& \mathrm{H}_{0}: \quad \beta_{2}=0 \\
& \mathrm{H}_{1}: \quad \beta_{2}>0
\end{aligned}
$$

Tabel 5. dapat dinyatakan bahwa terdapat pengaruh yang signifikan minat baca terhadap kemampuan memahami teks recount. Hal ini dibuktikan dengan perolehan nilai Sig. $0.00<0,05$ dan $t_{h}=5.096$. Salah satu dari sekian banyak faktor internal yang dapat mempengaruhi upaya meningkatkan pengetahuan dan keterampilannya adalah faktor minat. Setiap siswa memiliki minat yang berbeda terhadap sesuatu. Salah satunya adalah minat baca. Minat baca merupakan modal dasar bagi para siswa untuk menambah pengetahuannya. Seorang siswa yang memiliki minat baca tinggi, ia cenderung untuk banyak membaca senada dengan pendapat Rahim (2011: 28-29) orang yang mempunyai minat membaca yang kuat akan diwujudkannya dalam kesediaanya untuk mendapat bahan bacaan dan kemudian membacanya atas kesadaran sendiri. Dengan membaca siswa akan mendapat pengetahuan, terbiasa dengan pola-pola kalimat, bentuk paragraf, jenis bacaan, kosakata dan hal-hal lain yang menyangkut kebahasaan. Siswa pun dapat memahami suatu isi bacaan dengan mudah sebaliknya siswa akan sulit memahami isi bacaan jika siswa kurang memiliki minat baca hal ini seperti pendapat yang dikemukakan oleh Somadayo (2011: 3) mengemukakan bahwa rendahnya kemampuan membaca disebabkan oleh minat membaca siswa. Dengan demikian, minat baca dapat mempengaruhi kemampuan membaca pemahaman siswa.

\section{Simpulan}

Berdasarkan deskripsi data dari hasil penelitian dari tiga variabel yaitu, penguasaan kosakata, minat baca dan kemampuan memahami teks recount dan telah diuraikan dan di analisis oleh peneliti dalam bab sebelumnya maka dapat disimpulkan sebagai berikut:

1. Terdapat pengaruh yang signifikan penguasaan kosakata dan minat baca secara bersama-sama terhadap kemampuan memahami teks recount siswa SMP Negeri di Kabupaten Indramayu. Hal ini dibuktikan dengan perolehan nilai Sig $0.00<0,05$ dan $F_{h}=300.222$

2. Terdapat pengaruh yang signifikan penguasaan kosakata terhadap kemampuan memahami teks recount siswa SMP Negeri di kabupaten Indramayu. Hal ini dibuktikan dengan perolehan nilai Sig. $0.000<0,05$ dan $\mathrm{t}_{\mathrm{h}}=6.959$

3. Terdapat pengaruh yang signifikan minat baca terhadap kemampuan memahami teks recount siswa SMP Negeri di kabupaten Indramayu. Hal ini dibuktikan dengan perolehan nilai Sig. $0.00<0,05$ dan $t_{h}=5.096$

\section{Daftar Rujukan}

Rahim, F. (2011). Pengajaran Membaca di Sekolah Dasar. Jakarta : Sinar Grafika Offset. Ridwan. (2009). Rumus dan Data dalam Analisis Statistik untuk Penelitian, cetakan 3, Bandung: Alfabeta. Sumadoyo, S. (2011). Strategi dan Teknik Pembelajaran Membaca. Yogyakarta: Graha Ilmu. Tarigan, H. G. (2015). Berbicara Sebagai Suatu Keterampilan Berbahasa. Bandung: Angkasa. 